Sri Lanka J. Aquat. Sci. 14 (2009): 59-74

\title{
Feeding vitamins, antioxidants and cod liver oil enriched formulated feed influences the growth, survival and fatty acid composition of Macrobrachium rosenbergiii (de Man, 1879) postlarvae
}

\author{
M.G.I.S. PARAKARMA ${ }^{1^{*}}$, K.D. RAWAT ${ }^{2}$, G. VENKATESHWARLU ${ }^{3}$ and \\ A.K. REDDY ${ }^{4}$ \\ ${ }^{1}$ National Aquatic Resources Research and Development Agency, Crow \\ Island, Colombo 15, Sri Lanka \\ ${ }^{2}$ Aquaculture Division, Central Institute of Fisheries Education, Mumbai, \\ India \\ ${ }^{3}$ Division of Fish Nutrition and Biochemistry, Central Institute of Fisheries \\ Education, Mumbai, India \\ ${ }^{4}$ Division of Fish Genetics and Biotechnology, Central Institute of Fisheries \\ Education, Mumbai, India \\ *Corresponding author (E-mail: paraindrani@yahoo.com)
}

\begin{abstract}
Effects of feeding Macrobrachium rosenbergii postlarvae with a formulated feed enriched with four different media viz. vitamin E (feed F1), vitamin D (feed F2), cod liver oil (feed F3), astaxanthin (feed F4) on growth, survival and fatty acid composition of the postlarvae were investigated in comparison to the unenriched formulated feed (FC, control feed) using five groups of postlarvae with three replicates for each feed.

Results showed that the postlarvae fed with cod liver oil enriched feed (F3) had the highest weight gain (225.72 $\pm 9.05 \%)$, highest specific growth rate $(2.95 \pm 0.07 \%)$, and highest survival $(77.14 \pm 4.28 \%)$ as well as low food conversion ratio $(0.87 \pm 0.03)$ compared to the postlarvae fed with the other feeds. The postlarvae fed with astaxanthin (F4) or vitamin E (F1) enriched feed also showed relatively higher percentage weight gain, higher specific growth rate and lower food conversion ratios but the larval survival was better in the group fed with astaxanthin enriched feed. Postlarvae fed with cod liver oil enriched feed contained the highest levels of eicosapentaenoic acid (EPA) $(4.45 \pm 0.44 \%)$ in the body where as the highest levels of docosahexaenoic acid (DHA) and total highly unsaturated fatty acids (HUFA) in the body were observed in the postlarvae fed with astaxanthin enriched feed (F4) and vitamin E enriched feed (F1). The results indicate that the nutritional quality of formulated feed can be increased through enrichment, especially with astaxanthin or cod liver oil which could
\end{abstract}


improve the growth and survival of postlarvae of $M$. rosenbergii and the postlarval quality in relation to the fatty acid profile in the body.

\section{Introduction}

Macrobrachium rosenbergii is an important species for diversifying aquaculture due to its attributes of becoming gravid in captivity, availability of established techniques of seed production in hatcheries and grow-out culture, general absence of major disease problems, wide consumer acceptance and high market value. Its ability to grow in freshwater and low saline water prevents the need of sea water for farming and hence fresh water prawn culture is environmentally sustainable. Postlarval stages of crustaceans are mainly benthic in nature. They feed on detritus and other organic matter. In aquaculture, number of formulated feeds has been used for postlarvae. Formulated diets are attractive alternatives because they eliminate the need for costly and labour-intensive culture of live feeds. In addition, formulated diets are available throughout the year, conveniently stored, easy to use and their nutrient composition is easily modified. In some cases, commercial products are not very rich in all nutritional qualities. Nutritive quality of larval feed is more important, as growth and quality of postlarvae is highly correlated with quality seed production for aquaculture.

Highly unsaturated fatty acids (HUFA), especially eicosapentaenoic acid (20:5n-3) (EPA) and docosahexaenoic acid (22:6n-3) (DHA) have been identified as important nutrients for the early growth of fish and crustaceans. In crustaceans, the importance and essentiality of several poly-unsaturated fatty acids (PUFA) such as linoleic acid (18:2n-6), linolenic acid (18:3n-3), EPA and DHA to increase growth and survival of larvae and juveniles, to promote ovarian maturation in broodstock and to promote production of better quality eggs has been well known. De novo synthesis of these PUFA has not been observed in $M$. rosenbergii (Reigh and Stickney 1989), as well as in other shrimp species such as Penaeus. monodon and P. merguiensis (Kanazawa et al. 1979a; 1979b). Vitamin E, a structural component of cell membrane, has a specific role as an antioxidant; hence it could control peroxidation and autolysis of unsaturated fatty acids (Stephan et al. 1995). Recent studies indicate that astaxanthin is a powerful antioxidant, nearly 500 times more effective than vitamin $\mathrm{E}$ and astaxanthin could serve as a potent free-radical scavenger, while protecting HUFA and proteins against peroxidation. Vitamin D plays an important role in controlling metabolism of calcium within animals (Meyran et al. 1991, 1993). Mediating the uptake, storage and mobilization of calcium and phosphorus in crustaceans affect the growth rate as it is important for the shedding of exuviae.

The low quality seed may affect the final production of any farm and therefore the demand for such seed is reduced. Hence hatcheries should ensure the production of high quality seed. As HUFA play a major role in the early larval growth, their availability in larval feed is of paramount

(C) Sri Lanka Association for Fisheries and Aquatic Resources 
significance. In order to supplement HUFAs, cost effective enrichment methods have been developed using single or combinations of selected oils. In addition, various vitamins, antioxidants, carotenoids and many other combinations have been studied as enrichment media for obtaining high quality seeds in aquaculture. The objective of the present study was to evaluate the effect of feeding vitamin E, vitamin D, Cod liver oil and astaxanthin enriched, formulated feed on the growth performance and survival of the $M$. rosenbergii postlarvae and quality of postlarvae in relation to the fatty acid profile in the body.

\section{Materials and Methods}

\section{Source of postlarvae}

Healthy broodstock of $M$. rosenbergii was collected from the natural environment. They were reared in the broodstock tanks (1500 L) of the Giant Fresh Water Prawn Hatchery, Central Institute of Fisheries Education, Mumbai, India. Mature, berried females were transferred to $300 \mathrm{~L}$ circular fiberglass tanks having $12 \%$ salinity water. The larvae obtained from those mother prawns were reared in $300 \mathrm{~L}$ capacity larval rearing tanks and were initially fed with Artemia nauplii and later with egg custard, while gradually decreasing the salinity of water up to zero by the time the larvae reach the postlarval stage.

\section{Preparation of formulated feed with enrichments}

The composition of the formulated feed used in the present study is presented in Table 1. Locally available dried ground shrimps, soybean meal and casein were used as protein sources. All dry ingredients except vitamin, mineral mixture and oil were mixed thoroughly to prepare the dough. Vitamin and mineral mixture was mixed with the oil and then with the dough. The dough was passed through a hand noodle maker and the feed strings were dried under low temperature, at approximately $40-50{ }^{\circ} \mathrm{C}$ in an oven. Dried feed strings were crushed into small particles manually and stored in the refrigerator for further use.

Four different enrichment media viz. vitamin E emulsion, vitamin D emulsion, cod liver oil emulsion and astaxanthin emulsion were prepared using the ingredients given in Table 2 . These media were used to enrich the formulated feed to prepare four different experimental feeds (F1 to F4) by spraying the feed directly with emulsions of vitamin E (feed F1), D (feed F2), cod liver oil (feed F3) and astaxanthin (feed F4) respectively at the rate of $100 \mathrm{~mL} / 100 \mathrm{~g}$ feed followed by drying under the shade. 
Table 1. Composition of the formulated feed used in this study

Ingredients $\quad \mathrm{g} \mathrm{kg}^{-1}$

\begin{tabular}{|c|c|}
\hline Shrimp meal & 300 \\
\hline Soybean meal & 120 \\
\hline Casein & 200 \\
\hline Starch & 80 \\
\hline Cooking oil (sun flower) & 100 \\
\hline Dextrin & 50 \\
\hline Gelatin & 50 \\
\hline Cellulose powder & 50 \\
\hline Carboxy Methyl Cellulose & 20 \\
\hline Vitamin- Mineral mixture & 28 \\
\hline Vitamin B complex & 01 \\
\hline Vitamin $\mathrm{C}$ & 01 \\
\hline Total & 1000 \\
\hline \multicolumn{2}{|c|}{$\begin{array}{l}\text { Composition of vitamin-mineral mixture (Agrimin) (quantity/ kg) }: \text { Vitamin A } \\
\text { 6,25,000 IU; Vitamin D3 62,500 IU; Vitamin E } 250 \mathrm{mg} \text {; Nicotinamide } 1 \mathrm{~g} \text {; Cu } 312 \\
\mathrm{mg} \text {; Mg 6g; Fe } 1.5 \mathrm{~g} \text {; Zn 2.13 g; I } 156 \mathrm{mg} \text {; Se } 10 \mathrm{mg} \text {; Mn } 1.2 \mathrm{~g} \text {; Ca } 247.34 \mathrm{~g} \text {; P } \\
114.68 \mathrm{~g} \text {; S } 12.2 \mathrm{~g} \text {; Na } 5.8 \mathrm{mg} \text { K } 48.05 \mathrm{mg} \text {. } \\
\text { Composition of vitamin B complex (quantity/ g): Thiamin mononitrate } 20 \mathrm{mg} \text {; } \\
\text { Ribloflavin } 20 \mathrm{mg} \text {; Pyridoxin hydrochloride } 6 \mathrm{mg} \text {; vitamin B12 } 30 \mu \mathrm{g} \text {; Niacinamide } \\
200 \mathrm{mg} \text {; Ca pantothenate } 100 \mathrm{mg} \text {; Folic acid } 3 \mathrm{mg} \text {; Biotin } 200 \mu \mathrm{g}\end{array}$} \\
\hline
\end{tabular}

Table 2. Composition of the four emulsions used for enriching the formulated feed

\begin{tabular}{lcccc}
\hline Composition & $\begin{array}{c}\text { Vitamin E } \\
\text { emulsion }\end{array}$ & $\begin{array}{c}\text { Vitamin D } \\
\text { emulsion }\end{array}$ & $\begin{array}{c}\text { Cod liver } \\
\text { oil } \\
\text { emulsion }\end{array}$ & $\begin{array}{c}\text { Astaxanthin } \\
\text { emulsion }\end{array}$ \\
\hline Water & $40 \mathrm{~mL}$ & $40 \mathrm{~mL}$ & $40 \mathrm{~mL}$ & $40 \mathrm{~mL}$ \\
Egg yolk & $20 \mathrm{~mL}$ & $20 \mathrm{~mL}$ & $20 \mathrm{~mL}$ & $20 \mathrm{~mL}$ \\
Gelatin & $4.5 \mathrm{~g}$ & $4.5 \mathrm{~g}$ & $4.5 \mathrm{~g}$ & $4.5 \mathrm{~g}$ \\
Vitamin E & $6.0 \mathrm{~g}$ & - & - & - \\
Vitamin D & - & $5 \mu \mathrm{g}$ & - & - \\
Cod liver oil & - & - & $40 \mathrm{~mL}$ & - \\
Astaxanthin & - & - & - & $6 \mathrm{mg}$ \\
\hline
\end{tabular}




\section{Proximate composition of the formulated feed}

Proximate composition of the prepared four different enriched feed (F1, F2, F3 and F4) and unenriched feed (FC) were analyzed using the following procedures: moisture after drying the sample in an oven at $105{ }^{\circ} \mathrm{C}$ until constant weight; ash by incineration in a muffle furnace at $450{ }^{\circ} \mathrm{C}$ for 16 hours; protein ( $\mathrm{N}$ x 6.2) by the Kjeldahl method after acid digestion; lipids by diethyl ether extraction in a soxtec system; total carbohydrate and digestible energy value as described by Hasting (1969) and Halver (1976). Proximate compositions of prepared enriched feeds are presented in Table 3.

\section{Stocking and maintenance of postlarvae}

Fifteen plastic round tubs (50 L capacity) each containing $45 \mathrm{~L}$ of aerated fresh water were used for stocking $M$. rosenbergii postlarvae. The postlarvae (initial weight: $25.5 \pm 0.50-30.5 \pm 2.50 \mathrm{mg}$ ) were kept at a density of 700 individuals per $45 \mathrm{~L}$ fresh water in each tub. Fifteen tanks containing postlarvae were divided in to five groups, each containing 3 tanks. Postlarvae in one group of tanks were fed with unenriched formulated feed (FC). The postlarvae in the second, third, forth and fifth groups of tanks were fed with formulated feed enriched with vitamin E (F1), vitamin D (F2), cod liver oil (F3) and astaxanthin (F4) respectively. The tanks in each group were arranged to follow a completely randomized design. Shelters such as broken asbestos sheets and tiles were used as substrates to support postlarval settlements and to minimize the cannibalism. Cleaning of remaining feed, fecal matter, dead individuals and exuvia was carried out while two third volume of water was exchanged daily. The feed amount to be given in one day for each tank was calculated as per the body weight $(5 \%)$ and then it was divided into three portions to be offered three times a day $(7.00 \mathrm{hrs} 13.00 \mathrm{hrs}$ and $18.00 \mathrm{hrs}$ ).

\section{Growth performance and survival of postlarvae}

Effect of feeding differently enriched formulated feed on growth (percentage weight gain, specific growth rate) and survival of the postlarvae were assessed. Postlarval growth and survival was recorded for forty five days. The survival percentage was calculated as the final number of young $M$. rosenbergii in each tub as a percentage of the number of postlarvae stocked. Food Conversion Ratio (FCR) which is the feed amount needed to increase a single unit of the body weight and Feed Efficiency Ratio (FER), the reciprocal of the feed conversion ratio were also determined. 
Table 3. Proximate composition of the five different feed used for feeding postlarvae of $M$. rosenbergii

\begin{tabular}{|c|c|c|c|c|c|c|c|}
\hline \multirow[t]{2}{*}{ Feed } & \multicolumn{7}{|c|}{ \% dry weight } \\
\hline & Moisture & $\begin{array}{l}\text { Organic } \\
\text { Matter }\end{array}$ & $\begin{array}{c}\text { Crude } \\
\text { Protein }\end{array}$ & Lipid & $\begin{array}{c}\text { Total } \\
\text { Carbohydrate }\end{array}$ & Ash & $\begin{array}{l}\text { Digestible } \\
\text { Energy }\end{array}$ \\
\hline FC (Control, unenriched) & 20.71 & 90.50 & 34.12 & 10.99 & 45.39 & 9.50 & 416.95 \\
\hline F1 (Vitamin E enriched) & 26.53 & 92.00 & 36.17 & 10.29 & 45.54 & 8.00 & 419.45 \\
\hline F2 (Vitamin D enriched) & 21.65 & 91.00 & 38.24 & 10.86 & 41.9 & 9.00 & 418.30 \\
\hline F3 (Cod liver oil enriched) & 18.83 & 91.00 & 36.58 & 12.00 & 43.42 & 9.00 & 419.00 \\
\hline F4 (Astaxanthin enriched) & 20.24 & 91.50 & 38.64 & 11.50 & 41.36 & 8.50 & 423.50 \\
\hline
\end{tabular}




\section{Lipid extraction, preparation of fatty acid methyl esters and fatty acid analysis}

Total lipid of both enriched feed and postlarvae fed with different enriched feeds were extracted following the method of Folch et al. (1957). Feed and animal samples were separately homogenized in 10 volume of methanol (tissue w/v) fortified with $0.01 \%$ 2,6-di-t-butyl-p-hydroxytoluene (BHT; for avoiding the oxidation of lipid during analysis) followed by the 20 volume of chloroform (tissue $\mathrm{w} / \mathrm{v}$ ) in a Teflon coated tissue homogenizer (Superfit, India). The homogenate was first filtered with a funnel having a folded defatted filter paper to recover the liquid phase. The filtered volume was washed with 0.2 volume of $0.9 \% \mathrm{NaCl}$ solution and phases were vigorously mixed. The mixture was poured into a separating funnel and allowed to separate for few hours. The lower chloroform phase containing lipids was collected, evaporated under vacuum in a rotary evaporator. The residues were weighed to quantify the amount of lipid extracted. The lipid residue was stored under refrigeration. For the extraction of lipid from feed, the samples were first powdered and followed the same procedure.

The AOAC (1995) method was followed to esterify the lipid extract. Fatty Acid Methyl Esters (FAMEs) were prepared from the isolated lipids by heating with $0.5 \mathrm{~N}$ methanolic $\mathrm{NaOH}$. After evaporation and condensation started, samples were further heated for 5 minutes. It was treated with $5 \mathrm{~mL}$ Boron trifluoride/ methanol for esterification and again heated for two minutes. To this solution $5 \mathrm{~mL} \mathrm{n}$ - heptane was added to recover the methyl esters in organic phase. The mixture was washed with saturated $\mathrm{NaCl}$ solution and two phases were separated. The upper n-heptane layer was pippeted out and stored in $10 \mathrm{~mL}$ all glass vials until further analysis. The glass vials were pre-treated with pinch of pre-heated sodium sulphate to avoid excess water in the FAME.

Gas Chromatography/ Mass Spectrometry (GC/MS) measurements were performed on a Shimadzu QP2010 quadrupole mass spectrometer with isolation energy of $70 \mathrm{eV}$ operating in positive electronic impact set to 100 $\mu \mathrm{A}$ connected to a CG 8060 gas chromatograph (Shimadzu) equipped with a Carbowax ( $25 \mathrm{~m} \times 0.25 \mathrm{~mm} ; 0.25 \mu \mathrm{m}$ film thickness) column (Cromlab S.A.) and Helium as the carrier gas. Injection was performed in split mode at 250. FAMEs were separated at the constant pressure $(23.1 \mathrm{kPa})$ with the oven programme first at $50{ }^{\circ} \mathrm{C}$ for 2 minutes and then increasing at a rate of $10{ }^{\circ} \mathrm{C}$ $/ \mathrm{min}$ up to $230{ }^{\circ} \mathrm{C}$. The mass spectrometer was tuned to get the relative abundance of $\mathrm{m} / \mathrm{z}$ ranging from 40.00 to 550.00 . The fatty acids were identified referring to the retention time and GCMS library and presented in area percentage of total identified fatty acids.

In this study, fatty acid levels were analyzed in unenriched feed (FC) and cod liver oil enriched feed (F3) only, assuming that the fatty acid profile of unenriched feed group will not vary significantly among the other feed groups which were enriched with non lipid sources. In addition, fatty acid profile of $M$. rosenbergii postlarvae fed with control feed (FC) and the 
postlarvae fed with formulated feed enriched with different experimental emulsions (feed F1, F2, F3, and F4) were determined using GC/MS.

\section{Statistical analysis}

Results are presented as means \pm standard error of means (SEM). Differences among the control and treatment means were analyzed by oneway analysis of variance (One way ANOVA) followed by Duncan's new multiple range test. Differences were considered statistically significant when $\mathrm{P}<0.05$. Statistical analyses were carried out using the SPSS statistical package (SPSS Inc., Chicago, IL, USA).

\section{Results}

\section{Growth performance and survival of postlarvae}

Growth parameters and survival of postlarvae fed with different feeds are given in Table 4. Highest percentage weight gain and specific growth rate were recorded in the postlarvae fed with cod liver oil enriched feed followed by the postlarvae fed with vitamin E enriched feed and the postlarvae fed with astaxanthin enriched feed. The lowest percentage weight gain and specific growth rate were recorded in the postlarvae fed with the control feed (FC). Moreover, the lowest FCR $(0.87 \pm 0.03)$ was also recorded for the postlarvae fed with cod liver oil enriched feed whereas the highest FCR was obtained for the postlarvae fed with the unenriched feed (FC).

The results show that percentage survival was significantly $(\mathrm{p}<0.05)$ higher $(77.14 \pm 4.28 \%)$ in the postlarvae fed with cod liver oil enriched feed (F3) and astaxanthin enriched feed (F4) (76.43 $\pm 2.14 \%)$. The lowest survival $(52.85 \pm 2.85 \%)$ was recorded in the postlarvae fed with the unenriched feed (control feed).

\section{Fatty acid composition of enriched and unenriched feed}

Fatty acid profiles in the enriched feed and unenriched feed are given in Table 5. Among HUFA contents, the percentage arachidonic acid (C20: $4 n-6)$ was $0.31 \pm 0.06 \%$ in the feed enriched with cod liver oil. However, arachidonic acid was not detected in the unenriched feed. In cod liver oil enriched feed, the levels of EPA (C20:5n-3), DHA (C22;6n-3) and n3/n6 ratio were $4.09 \pm 0.05 \%, 3.73 \pm 0.18 \%$ and $0.37 \pm 0.02$ respectively where as in the unenriched feed (control), the corresponding levels were $0.39 \pm 0.06 \%$, $0.28 \pm 0.04 \%$ and $0.02 \pm 0.00$ respectively. 
Table 4. Growth parameters and survival of M. rosenbergii postlarvae fed with feed enriched with different emulsions

\begin{tabular}{|cccccccc}
\hline \hline Feed & $\begin{array}{c}\text { Initial } \\
\text { weight } \\
\text { (mg) }\end{array}$ & $\begin{array}{c}\text { Final } \\
\text { weight } \\
\mathbf{( m g )}\end{array}$ & $\begin{array}{c}\text { \% } \\
\text { Weight } \\
\text { Gain }\end{array}$ & FCR & FER & $\begin{array}{c}\text { SGR } \\
(\%)\end{array}$ & $\begin{array}{c}\text { Survival } \\
\mathbf{( \% )}\end{array}$ \\
\hline FC (Control, unenriched) & $25.5 \pm 0.5$ & $41.0^{\mathrm{a}} \pm 0.00$ & $60.84^{\mathrm{a}} \pm 3.15$ & $2.92^{\mathrm{d}} \pm 0.17$ & $0.34^{\mathrm{a}} \pm 0.04$ & $1.18^{\mathrm{a}} \pm 0.10$ & $52.85^{\mathrm{a}} \pm 2.85$ \\
F1 (Vitamin E enriched) & $28.5 \pm 2.5$ & $66.0^{\mathrm{c}} \pm 3.00$ & $132.44^{\mathrm{c}} \pm 9.86$ & $1.31^{\mathrm{b}} \pm 0.01$ & $0.76^{\mathrm{c}} \pm 0.0$ & $2.10^{\mathrm{c}} \pm 0.18$ & $57.00^{\mathrm{ab}} \pm 3.57$ \\
F2 (Vitamin D enriched) & $26.0 \pm 2.4$ & $53.0^{\mathrm{b}} \pm 5.10$ & $103.90^{\mathrm{b}} \pm 0.45$ & $1.88^{\mathrm{c}} \pm 0.17$ & $0.56^{\mathrm{b}} \pm 0.01$ & $1.78^{\mathrm{b}} \pm 0.18$ & $60.71^{\mathrm{b}} \pm 3.57$ \\
F3 (Cod liver oil enriched) & $23.5 \pm 0.5$ & $76.5^{\mathrm{d}} \pm 0.50$ & $225.72^{\mathrm{d}} \pm 9.05$ & $0.87^{\mathrm{a}} \pm 0.03$ & $1.14^{\mathrm{d}} \pm 0.04$ & $2.95^{\mathrm{d}} \pm 0.07$ & $77.14^{\mathrm{c}} \pm 4.28$ \\
F4 (Astaxanthin enriched) & $30.0 \pm 1.0$ & $69.0^{\mathrm{c}} \pm 1.00$ & $130.14^{\mathrm{c}} \pm 4.33$ & $1.49^{\mathrm{b}} \pm 0.03$ & $0.66^{\mathrm{bc}^{\mathrm{c}} \pm 0.01}$ & $2.08^{\mathrm{c}} \pm 0.04$ & $76.43^{\mathrm{c}} \pm 2.14$ \\
\hline
\end{tabular}

Data are presented as mean \pm SEM, $n=3$, Values in the same column with different superscripts differ significantly $(\mathrm{p}<0.05)$.

FCR- Food conversion ratio; FER- Feed efficiency ratio, SGR-Specific growth rate 
Table 5. Fatty acid profile (\%) of unenriched feed (FC) and cod liver oil enriched feed (F3)

\begin{tabular}{|c|c|c|}
\hline Fatty acid & Unenriched Feed & Cod liver oil enriched feed \\
\hline C6:0 & $0.08 \pm 0.04$ & - \\
\hline C8:0 & $0.06 \pm 0.04$ & $0.12 \pm 0.06$ \\
\hline C12:0 & $0.16 \pm 0.05$ & $0.10 \pm 0.01$ \\
\hline C14:0 & $0.54 \pm 0.08$ & $3.29 \pm 0.18$ \\
\hline C15:0 & $0.08 \pm 0.02$ & $0.31 \pm 0.04$ \\
\hline C16:0 & $11.78 \pm 0.23$ & $12.64 \pm 0.36$ \\
\hline C17:0 & $0.27 \pm 0.15$ & $0.32 \pm 0.03$ \\
\hline C18:0 & $03.92 \pm 0.23$ & $5.24 \pm 0.21$ \\
\hline C20:0 & $0.44 \pm 0.21$ & $0.29 \pm 0.03$ \\
\hline C22:0 & $0.56 \pm 0.09$ & $0.40 \pm 0.06$ \\
\hline SAFA & $17.91 \pm 0.03$ & $22.74 \pm 0.82$ \\
\hline C16:1n-7 & $1.4 \pm 0.26$ & $4.29 \pm 0.33$ \\
\hline C18:1n-9 & $38.09 \pm 0.18$ & $29.83 \pm 0.29$ \\
\hline C18:1n-5 & - & $0.07 \pm 0.02$ \\
\hline C20:1n-9 & $0.87 \pm 0.03$ & $4.53 \pm 0.14$ \\
\hline C22:1n-9 & - & $4.31 \pm 0.30$ \\
\hline MUFA & $40.39 \pm 0.05$ & $43.03 \pm 1.08$ \\
\hline C18:2n-6 & $41.07 \pm 0.47$ & $24.74 \pm 0.16$ \\
\hline C18:3n-3 & $0.20 \pm 0.03$ & $0.73 \pm 0.04$ \\
\hline PUFA & $41.27 \pm 0.43$ & $25.47 \pm 0.20$ \\
\hline C20:4n-6 & - & $0.31 \pm 0.06$ \\
\hline C20:4n-3 & - & $0.60 \pm 0.42$ \\
\hline C20:5n-3 & $0.39 \pm 0.06$ & $4.09 \pm 0.05$ \\
\hline C22:6n-3 & $0.28 \pm 0.04$ & $3.73 \pm 0.18$ \\
\hline HUFA & $0.67 \pm 0.10$ & $8.73 \pm 0.48$ \\
\hline n-3 PUFA & $0.20 \pm 0.03$ & $0.73 \pm 0.04$ \\
\hline n-3HUFA & $0.67 \pm 0.10$ & $8.42 \pm 0.55$ \\
\hline n-6PUFA & $41.07 \pm 0.47$ & $24.74 \pm 0.16$ \\
\hline n-6HUFA & - & $0.31 \pm 0.06$ \\
\hline n3/n6 & $0.02 \pm 0.00$ & $0.37 \pm 0.02$ \\
\hline
\end{tabular}

Results are presented as mean $\pm \mathrm{SEM}, \mathrm{n}=3$. 


\section{Fatty acid profile of $M$. rosenbergii postlarvae fed with the enriched feed}

The fatty acids detected from the postlarvae fed with unenriched feed and the feed enriched with different enriched media are given in Table 6. Palmitic acid (C16:0) was the most abundant saturated fatty acid (SAFA) in the postlarvae. Postlarvae fed with the unenriched feed (control group) had significantly higher $(p<0.05)$ levels of palmitic acid $(28.31 \pm 0.33 \%)$ compared to the levels in the postlarvae fed with the enriched control feed $(8.55 \pm 0.04 \%)$. Significantly higher $(\mathrm{p}<0.05)(10.40 \pm 0.39 \%)$ stearic acid (C18:0) levels were recorded in the postlarvae fed with feed enriched with cod liver oil where as the lowest levels were recorded in the postlarvae fed with astaxanthin enriched feed $(8.01 \pm 0.62 \%)$ and unenriched feed $(8.55 \pm$ $0.44 \%)$. Oleic acid (C18:1n-9) was the prominent mono unsaturated fatty acid (MUFA) in the postlarvae. Its percentage was significantly higher $(\mathrm{p}<0.05)$ $(34.04 \pm 0.07 \%)$ in the control group compared to the postlarvae fed with the enriched feed.

Of the poly unsaturated fatty acids (PUFA), linoleic acid (C18:2n-6) content was the lowest $(14.58 \pm 0.13 \%)$ in the control group compared to the levels in the postlarvae fed with the enriched feed where as the highest linoleic acid content $(26.87 \pm 0.23 \%)$ was detected in the in the postlarvae fed with astaxanthin enriched feed. In contrast, linolenic acid (C18:3n-3) content was significantly higher $(0.75 \pm 0.19 \%)$ in the control group compared to the postlarvae fed with enriched feed. The highest total HUFA levels were detected in the postlarvae fed with vitamin E enriched feed $(9.55 \pm 0.18 \%)$ and in the postlarvae fed with astaxanthin enriched feed $(9.44 \pm 0.29 \%)$. Among HUFA, significantly higher arachidonic acid (C20: 4n-6) levels were detected in the postlarvae fed with vitamin $\mathrm{E}$ and vitamin $\mathrm{D}$ enriched feed compared to the control group. EPA $(\mathrm{C} 20: 5 n-3)$ content was higher $(\mathrm{p}<0.05)$ in the postlarvae fed with cod liver oil enriched feed $(4.45 \pm 0.44 \%)$ and astaxanthin enriched feed $(4.03 \pm 0.06 \%)$ compared to the control group $(2.40 \pm 0.40 \%)$. DHA (C22:6n-3) level was significantly higher in the postlarvae fed with the enriched feed compared to the control group. The highest DHA levels were detected in the postlarvae fed with the feed enriched with astaxanthin (F4) or vitamin $\mathrm{E}$ (F1).

\section{Discussion}

In general, growth of animal vary with several factors; the food availability, environmental factors, the social hierarchy of the population, nutritional qualities of the food etc. In this study, it can be suggested that, dietary n-3 HUFA level might have affected the growth of postlarvae. Das et al.(2007) and Prabitha (2007) observed higher weight gain and specific growth rate of $M$. rosenbergii postlarvae fed with HUFA enriched Moina micrura. Higher specific growth rate of $P$. monodon postlarvae fed with HUFA enriched Artemia has been observed by Immanuel et al. (2007). Present results are in agreement with their findings. 
Table 6: Fatty acid profile (\%) of $M$. rosenbergii postlarvae(PLs) fed with formulated feed enriched with different emulsions; FC- unenriched feed, F1feed enriched with vitamin E, F2-feed enriched with vitamin D, F3-feed enriched with cod liver oil and F4-feed enriched with astaxanthin (F4)

\begin{tabular}{|c|c|c|c|c|c|}
\hline \multirow[t]{2}{*}{ Fatty acid } & \multicolumn{5}{|c|}{$\%$ individual fatty acids among total identified fatty acids } \\
\hline & $\begin{array}{l}\text { PLs fed } \\
\text { with FC }\end{array}$ & $\begin{array}{l}\text { PLs fed with } \\
\text { F1 }\end{array}$ & $\begin{array}{l}\text { PLs fed } \\
\text { with F2 }\end{array}$ & $\begin{array}{c}\text { PLs fed with } \\
\text { F3 }\end{array}$ & $\begin{array}{l}\text { PLs fed } \\
\text { with F4 }\end{array}$ \\
\hline C12:0 & $0.25^{\mathrm{a}} \pm 0.02$ & $0.51^{b} \pm 0.04$ & $0.71^{\mathrm{c}} \pm 0.11$ & $0.47^{\mathrm{b}} \pm 0.09$ & - \\
\hline $\mathrm{C} 14: 0$ & $0.33^{\mathrm{a}} \pm 0.04$ & $1.74^{\mathrm{b}} \pm 0.37$ & $1.63^{\mathrm{b}} \pm 0.07$ & $1.69^{\mathrm{b}} \pm 0.17$ & $1.70^{\mathrm{b}} \pm 0.13$ \\
\hline $\mathrm{C} 15: 0$ & $0.45^{\mathrm{a}} \pm 0.14$ & $0.44^{\mathrm{a}} \pm 0.12$ & $0.44^{\mathrm{a}} \pm 0.12$ & $0.40^{\mathrm{a}} \pm 0.01$ & $0.97^{\mathrm{b}} \pm 0.05$ \\
\hline $\mathrm{C} 16: 0$ & $28.31^{\mathrm{c}} \pm 0.33$ & $24.58^{\mathrm{ab}} \pm 0.46$ & $25.31^{\mathrm{b}} \pm 0.20$ & $26.32^{\mathrm{b}} \pm 0.17$ & $23.16^{\mathrm{a}} \pm 0.71$ \\
\hline $\mathrm{C} 17: 0$ & $0.49^{\mathrm{a}} \pm 0.07$ & $0.48^{\mathrm{a}} \pm 0.02$ & $0.59^{\mathrm{b}} \pm 0.03$ & $0.69^{c} \pm 0.07$ & $1.70^{\mathrm{d}} \pm 0.06$ \\
\hline $\mathrm{C} 18: 0$ & $8.55^{\mathrm{a}} \pm 0.04$ & $9.81^{\mathrm{b}} \pm 0.36$ & $9.81^{\mathrm{b}} \pm .045$ & $10.40^{c} \pm 0.39$ & $8.01^{\mathrm{a}} \pm 0.62$ \\
\hline SAFA & $39.7^{\mathrm{d}} \pm 0.44$ & $37.57^{b} \pm .26$ & $38.54^{\mathrm{c}} \pm 0.76$ & $39.98^{\mathrm{d}} \pm 0.22$ & $35.55^{\mathrm{a}} \pm 0.31$ \\
\hline C16:1n-9 & - & - & $0.50^{\mathrm{a}} \pm 0.08$ & - & $0.49^{\mathrm{b}} \pm 0.06$ \\
\hline C16:1n-7 & $4.21^{\mathrm{b}} \pm 0.30$ & $0.44^{\mathrm{a}} \pm 0.09$ & - & - & - \\
\hline C18:1n-9 & $34.04^{\mathrm{c}} \pm 0.07$ & $27.87^{\mathrm{b}} \pm .25$ & $25.91^{\mathrm{a}} \pm 0.35$ & $26.35^{\mathrm{a}} \pm 0.46$ & $28.5^{\mathrm{b}} \pm 0.45$ \\
\hline C18:1n-6 & - & - & $3.07^{\mathrm{b}} \pm 0.13$ & - & $2.76^{\mathrm{a}} \pm 0.21$ \\
\hline C18:1n-5 & - & $1.61^{\mathrm{a}} \pm 0.26$ & - & $3.35^{\mathrm{b}} \pm 0.09$ & - \\
\hline C20:1n-9 & - & - & - & $0.42^{\mathrm{a}} \pm 0.16$ & - \\
\hline MUFA & $38.26^{\mathrm{d}} \pm 0.23$ & $29.92^{\mathrm{b}} \pm 0.10$ & $29.54^{\mathrm{a}} \pm 0.40$ & $30.13^{b} \pm 0.53$ & $31.82^{\mathrm{C}} \pm 0.73$ \\
\hline C18:2n-6 & $14.58^{\mathrm{c}} \pm 0.13$ & $22.70^{\mathrm{b}} \pm 0.30$ & $22.93^{\mathrm{b}} \pm 0.24$ & $21.11^{\mathrm{a}} \pm 0.02$ & $21.87^{\mathrm{a}} \pm 0.23$ \\
\hline C18:3n-3 & $0.75^{\mathrm{b}} \pm 0.19$ & - & - & $0.27^{\mathrm{a}} \pm 0.01$ & $0.30^{\mathrm{a}} \pm 0.05$ \\
\hline$C 20: 2 n-7$ & $0.27^{\mathrm{a}} \pm 0.04$ & - & $0.56^{\mathrm{b}} \pm 0.03$ & - & - \\
\hline C20:2n-6 & - & - & - & $0.66^{\mathrm{a}} \pm 0.20$ & - \\
\hline$C 20: 3 n-3$ & - & $0.25^{\mathrm{a}} \pm 0.25$ & - & - & - \\
\hline PUFA & $15.61^{\mathrm{a}} \pm 0.28$ & $22.95^{\mathrm{c}} \pm 0.55$ & $23.49^{c} \pm 0.27$ & $22.05^{b} \pm 0.20$ & $22.18^{b} \pm 0.29$ \\
\hline$C 20: 4 n-6$ & $2.89^{\mathrm{b}} \pm 0.35$ & $3.64^{\mathrm{c}} \pm 0.08$ & $3.83^{\mathrm{c}} \pm 0.36$ & $2.18^{\mathrm{a}} \pm 0.19$ & $2.77^{\mathrm{a}} \pm 0.32$ \\
\hline$C 20: 5 n-3$ & $2.40^{\mathrm{a}} \pm 0.40$ & $3.61^{c} \pm 0.25$ & $2.97^{\mathrm{b}} \pm 0.20$ & $4.45^{\mathrm{d}} \pm 0.44$ & $4.03^{c} \pm 0.06$ \\
\hline$C 22: 6 n-3$ & $1.08^{\mathrm{a}} \pm 0.02$ & $2.30^{\mathrm{d}} \pm 0.15$ & $1.73^{\mathrm{c}} \pm 0.21$ & $1.21^{\mathrm{b}} \pm 0.15$ & $2.64^{\mathrm{e}} \pm 0.08$ \\
\hline HUFA & $6.37^{\mathrm{a}} \pm 0.06$ & $9.55^{\mathrm{d}} \pm 0.18$ & $8.53^{c} \pm 0.77$ & $7.84^{b} \pm 0.10$ & $9.44^{\mathrm{d}} \pm 0.29$ \\
\hline n-3 PUFA & $0.75^{\mathrm{b}} \pm 0.19$ & $0.25^{\mathrm{a}} \pm 0.25$ & - & $0.27^{\mathrm{a}} \pm 0.01$ & $0.30^{\mathrm{a}} \pm 0.05$ \\
\hline n-3 HUFA & $3.48^{\mathrm{a}} \pm 0.42$ & $5.91^{c} \pm 0.10$ & $4.70^{\mathrm{b}} \pm 0.41$ & $5.66^{\mathrm{c}} \pm 0.29$ & $6.67^{\mathrm{d}} \pm 0.02$ \\
\hline n-6 PUFA & $14.58^{\mathrm{a}} \pm 0.13$ & $22.70^{c} \pm 0.30$ & $22.93^{\mathrm{c}} \pm 0.24$ & $21.7^{b} \pm 0.18$ & $26.87^{\mathrm{d}} \pm 0.23$ \\
\hline n-6 HUFA & $2.89^{b c} \pm 0.35$ & $3.64^{\mathrm{c}} \pm 0.08$ & $3.83^{\mathrm{d}} \pm 0.36$ & $2.18^{\mathrm{a}} \pm 0.19$ & $2.77^{b} \pm 0.32$ \\
\hline n3/n6 & $0.24^{\mathrm{b}} \pm 0.02$ & $0.23^{\mathrm{b}} \pm 0.00$ & $0.18^{\mathrm{a}} \pm 0.01$ & $0.2^{\mathrm{b}} \pm 0.01$ & $0.10^{\mathrm{a}} \pm 0.00$ \\
\hline
\end{tabular}

Data are presented as mean \pm SEM, $n=3$

Values in the same row with different superscripts differ significantly $(p<0.05)$

In the present study, dietary HUFA in the enriched feed may have contributed to the high survival percentage of postlarvae. In addition to that, astaxanthin, the high level antioxidant could have supported the lipid and/or fatty acid protection in the enriched diet as well as in postlarval tissue. As 
they are involved in prevention of lipid deterioration, it might have affected survival. HUFAs enhance the survival of fish larvae during metamorphosis (Dhert et al. 1990) and act as a growth factor in crustaceans (Kanazawa et al. 1979a). Xu et al. (1993) revealed that, 1\% DHA level in the diet in Penaeus chinensis gave the highest survival. Our results indicated that, enrichment with lipid source is effective for their growth and also it can be suggested that, vitamin E and astaxanthin would have helped for the protection of lipid and/ or fatty acids in the postlarvae body tissue. Many authors, worked on supplying enriched feed to fish and crustaceans have observed that, lipid levels in the diet can enhance the growth. Significantly higher growth of Litopenaeus vannamei postlarvae which were fed with $2 \%$ fish oil (low n-3 HUFA), $200 \mathrm{mg} \mathrm{kg}^{-1} \alpha$ tocopherol acetate and $100 \mathrm{mg} \mathrm{kg}^{-1}$ ascorbic acid was recorded by Ruff et al. (2001). Higher weight gain was observed by Immanuel et al. (2007) when P. monodon postlarvae were fed with HUFA enriched Artemia.

According to our results, the survival percentage of the postlarvae fed with cod liver oil enriched feed (F3) or astaxanthin enriched feed (F4) was higher than the postlarvae fed with the other feeds. The significantly lowest survival in this study was recorded in control group. This suggests that dietary HUFA can enhance the survival and as antioxidants involve in the protection of lipids in the body, it would also help for the better survival. In a previous study, survival of $P$. indicus postlarvae fed with lipid enriched Artemia nauplii was higher than controls (Immanuel et al. 2001). Immanuel et al. (2007) observed that significantly higher survival of P. monodon postlarvae fed with probiont-encapsulated Artemia diets, while lowest survival was recorded with unenriched Artemia fed postlarvae. The results of the present study support these findings. But according to Rees et al.(1994), very high n-3 HUFA may lead to detrimental effects on both growth and survival of $P$. monodon postlarvae. Formulated diets may not closely match the nutritional requirements of prawns (Tidwell et al. 1997). However, differences in experimental design, postlarval age, duration of the experimental period, feed management and most likely, differences in the composition and quality of the emulsions used in other studies may have affected the differences of various experimental results.

The fatty acid profile of body tissue is a key factor as it has been proposed for evaluating quality of seed (Arellano 1990). Fatty acid composition of the animal body tissue, mainly n-3 HUFA, is correlated with their susceptibility to various diseases i.e. immunity, and ability to tolerate the unfavorable environmental factors. If their ability to synthesize those fatty acids is lacking and/or very poor, providing those fatty acids exogenously (Watanabe et al. 1974; Pillai et al. 2003) will minimize the problem. Palmitic acid (C16:0) was the major fatty acid among saturated fatty acid group in the postlarvae fed with all types of feed. Highest level of palmitic acid was observed in control group postlarvae fed with unenriched feed, suggesting that enrichment of feed with PUFA rich cod liver oil reduces the relative percentage of saturated fatty acids. Linolenic acid levels (C18:3n-3) in the 
different treatment groups were considerably less in amount. It indicates that the dietary linolenic acid does not affect the tissue linolenic acid level. These lower levels of tissue linolenic acid indicate the inability of postlarvae to synthesize the linolenic acid in tissue. Reigh and Stickney (1989) have also mentioned this earlier. Results show that the feeding of postlarvae with cod liver oil enriched feeds would enhance the EPA level of body tissue. In this study, it was observed that, body tissue of postlarvae fed with feed enriched with astaxanthin also shows a remarkable increment of EPA level. However, EPA levels in postlarvae fed with different feeds varied within a narrow range. Elevated levels of specific fatty acids in larval tissue compared to dietary amounts have been referred to as incorporation efficiency (Castell et al. 1994). However, in this study, DHA levels in the postlarvae fed with different feeds did not show a remarkable correlation between dietary DHA level. Tissue DHA levels of postlarvae fed with non lipid enriched feed were greater than their dietary DHA level, but cod liver oil enriched feed fed postlarvae showed lower levels than dietary levels. Therefore, further research is needed in this regard. According to Stephan et al. (1995), vitamin E being an antioxidant, it might have reduced auto-oxidation of the lipids in the tissue of postlarvae and thus became responsible for elevated total HUFA level of postlarvae fed with vitamin E enriched feed.

\section{Acknowledgements}

We are indebted to Dr. Dilip Kumar, Director and Dr. M.P.S. Kohli, HOD, Aquaculture division, Central Institute of Fisheries Education (CIFE), Mumbai, India for providing the facilities for carrying out this research work. The scholarship offered to the first author and the financial support by the Council for Agricultural Research Policy and National Aquatic Resources Research and Development Agency, Sri Lanka is highly acknowledged.

\section{References}

AOAC, 1995.

Official Methods of Analysis : AOAC International, Vol.1, $16^{\text {th }}$ edn. (P.A Cunniff, ed.). AOAC International, Arlington, USA

Arellano, E., 1990.

Fatty acid composition of wild and cultured Penaeus vannamei as a method to evaluate postlarval quality. In: Abstracts of the World Aquaculture Society Meeting. National Research Council Canada, Ottawa, pp 50.

Castell, J. D., J. G Bell,, D. R. Tocher \& J. R . Sargent 1994.

Effects of purified diets containing different combinations of arachidonic and docosahexaenoic acid on survival, growth and fatty acid composition of juvenile turbot Scophthalmus maximus. Aquaculture 128: 315-333. 
Das, S.K., V.K. Tiwari, G Venkateshwarlu, A.K. Reddy, J. Parhi, P.Sharma, \& J.K Chetti 2007.

Growth, survival and fatty acid composition of Macrobrachium rosenbergii (de Man, 1879) postlarvae fed HUFA enriched Moina micrura. Aquaculture 269: 464-475.

Dhert, P., P.Lavens, M Duray, \& P. Sorgeloos 1990.

Improved larval survival at metamorphosis of Asian sea bass (Lates calcarifer) using w3-HUFA- enriched live food. Aquaculture 90: 6374.

Folch, J., M.Lees, \& G. H Slone- Satanley 1957.

A simple method for the isolation and purification of total lipids from animal tissues. Journal of Biological Chemistry 226. 497-509.

Halver, J. E., 1976.

The nutritional requirements of cultivated warm water and cold water fish species. Paper No. 31. FAO Technical Conference on Aquaculture, pp 9. Kyoto.

Hastings, W. H. 1969.

Nutritional score. In: Fish in Research (O.W. Newhaus \& J.E Halver eds.), pp 263-292, Academic press, New York.

Immanuel, G., A. Palavesan \& M. Petermarian 2001.

Effects of feeding lipid enriched Artemia nauplii on survival, growth, fatty acids and stress resistance of post larvae Penaeus indicus. Asian Fisheries Science 14:377-388.

Immanuel, G., T Citarasu, V Sivaram, , M.M. Bahu \& A. Palavesam 2007.

Delivary of HUFA, probionts and biomedicine through bioencapsulated Artemia as a means to enhance the growth, survival and reduce the pathogenecity in shrimp Penaeus monodon post larvae. Aquaculture International 15: 137-152.

Kanazawa, A., S. Teshima, , K. Ono \& K. Chalayondeja 1979a.

Biosynthesis of fatty acids from acetate in the prawns, Penaeus monodon and Penaeus merguensis. Memoirs of Faculty of Fisheries, Kagoshima University 28: 21-26.

Kanazawa, A., S. Teshima,, K. Ono \& K. Chalayondeja,1979b.

Biosynthesis of fatty acids from palmitic acid in the prawns, Penaeus monodon and Penaeus merguensis. Memoirs of Faculty of Fisheries, Kagoshima University 28:17- 20.

Meyran, J. C., , M.C. Chapuy, S.A. Arnaud, E. Sellam \& F. Graf,1991.

Variations of vitamin D- like reactivity in the crustacean Orchestia cavimana during the molt cycle. General and Comparative Endocrinology, 84:115-120.

Meyran, J. C., E. Sellam \& J. Fournie 1993.

Action of 1,25- dyhydroxivitamin D3 on calcium metabolism in the crustacean Orchestia cavimana during the molt cycle. Comparative Biochemistry and Physiology 106A:75-80.

Prabitha, T.P. 2007. 
Evaluation of HUFA, vitamins C and E enriched Moina for post larvae of Macrobrachium rosenbergii (de Man) Master's thesis, Central Institute of Fisheries Education, India.

Pillai, D., T., James, A. Joshep \& K.H Vadher 2003.

Enrichment of live feed with HUFA: Effect on Macrobrachium rosenbergii (de Man). Proceedings of the International Symposium on Freshwater prawns. pp 541-544, College of Fisheries, Kerala Agricultural University, Kochi, Kerala, India.

Rees, J. F., K Cure, S.Piyatiratitivorakul, P Sorgeloos \& P. Menasveta. 1994. Highly unsaturated fatty acid requirements of Penaeus monodon post larvae: an Experimental approach based on Artemia enrichment. Aquaculture 122, 193-207.

Reigh, R. C. \& R. R. Stickney 1989.

Effects of purified fatty acids of the fatty acid composition of the freshwater shrimp, Macrobrachium rosenbergii. Aquaculture 77: 157-174.

Ruff, N., P. Lavens, J.Z. Huo, P. Sorgeloos, H.J Nelis \& A. DeLeenheer 2001.

Antioxident effect of dietary tocopherol and ascorbic acid on growth and survival of Litopenaeus vannamei postlarvae. Aquaculture International 9: 115-126.

Stephan, G., , J. Guillaume \& F. Lamour 1995.

Lipid peroxidation in turbot (Scophthalmus maximus) tissue: effect of dietary vitamin $E$ and dietary n-6 or n-3 polyunsaturated fatty acids. Aquaculture 130 (2-3): 251-268.

Tidwell, J., G. Schulmeister, C Mahl \& Coyles 1997.

Growth, survival and biochemical composition of fresh water prawns Macrobrachium rosenbergii fed natural food organisms under controlled conditions. Journal of World Aquaculture Society 28(2): 123-132.

Watanabe, T., C. Ogino, Y. Koshishi \& T. Matsunga 1974.

Requirement of rainbow trout for essential fatty acids. Bulletin of Japanese Society of Fisheries Science 40: 493-499.

Xu, X., J. Wenjuan, J. D. Castell \& R. Dor 1993.

The nutritional value of dietary $n-3$ and $n-6$ fatty acids for the Chinese prawn (Penaeus chinensis). Aquaculture 118: 277-285. 